\title{
Research on Collaborative Innovation of Higher Education and Manufacturing Development
}

\author{
Chun-Mei LI ${ }^{1, a}$ and Wei-Na LIU ${ }^{2, b, *}$
}

${ }^{1}$ College Of Optical And Electronical Information Changchun University of Science and Technologe, Mechanical And Electrical Engineering ,Changchun City, Jilin Province, China.

${ }^{2}$ College Of Optical And Electronical Information Changchun University of Science and Technologe, Mechanical And Electrical Engineering ,Changchun City, Jilin Province, China .

a450734640@qq.com, ${ }^{\mathrm{b}}$ wnliu77@163.com

*Wei-Na LIU

Keywords: Higher education, Manufacturing, Collaborative innovation ability

\begin{abstract}
This article starts from Countermeasures and Suggestions of higher education and Collaborative Innovation of manufacturing development, Combined with the actual situation of the regional schools, It's been described preliminary results of collaborative innovation of higher education and manufacturing development, Established college of new think tanks with characteristics of Jilin. About of innovation mechanism has implemented the reform.
\end{abstract}

\section{One. Countermeasures and Suggestions on Collaborative Innovation of Higher Education and Manufacturing Development}

\section{Improve the Mechanism of Incentive and Communication}

Knowledge of innovation management to now, the output and contribution who scientific workers is the basis for evaluating innovation and management. Should create a perfect system of innovation incentive if we cultivate Innovation consciousness about anyone.

Higher education should be as far as possible tolerance error in the development in future. To reward innovation and double reward of material and spiritual for the act of innovation and risk-taking. Only in this way ,scientists make bold assumptions and be cautious. In addition, high education also attaches great importance to cross-departmental and cross-organizational cooperation. we create a "win-win" cooperation situation through cooperation with external universities, external enterprises, research institutes, government departments and other units.

In the actual work of management, discover innovative behavior, give positive incentive immediately, when you find bad behavior, you should stop it and punish it.

\section{Improve the Transformation Efficiency of Scientific Research Achievements}

Higher education attaches great importance to cooperation project with external enterprise, achieved good social benefits and economic benefits. The personnel of the institute and the company who are sent to the university to work together to solve the technical problems, the study of the basic theory is efficient and highly productive.

But the efficiency of the results of higher education still needs to be improved to a new height, It shouldered the task of revitalizing our country's equipment manufacturing industry. Therefore, market demand should be fully investigated. Only in this way, the higher education can continue to maintain its competitive edge in the competition and strengthen its core competitiveness.

\section{To Strengthen the Guidance of Government's Policy}

\section{Provide a Favorable Project Environment}

The government should build favorable environment of the project, guided by collaborative innovation of the higher education and the cooperative unit. To build a whole value chain in the education, organic coordinated innovation system. 


\section{Create a More Favorable Policy Environment}

Local governments at all levels have increased spending on education in real terms, more research and development, Continue to support innovative work and encourage the use of innovative resources. Finally, a good situation of innovation cooperation such as universities, enterprises and research institutes is formed.

\section{To Ensure the Implementation of the Relevant System}

Improve the infrastructure related to collaborative innovation, Perfect laws and regulations, Protect the environment through direct intervention of government, It provides a strong guarantee for the success of the collaborative innovation of education. At the same time, local governments need to promote information related to collaborative innovation. With soft environment as important foothold and maintain a unique advantage in hard environments, attract and introduce innovative talents.

\section{Local government is the Exogenous Force of Collaborative Innovation of Higher Education}

The government needs to build a basic security system, to take advantage of local governments at all levels, for local governments to enhance their ability to innovate continuously.

\section{Two. Preliminary Results on Collaborative Innovation of Higher Education and Manufacturing Development}

\section{Construction of a New College Think Tank with Jilin Characteristics}

At the higher education teaching fusion collaborative innovation center think tank construction, make the result of think tank that based on the important theoretical and practical problems that need to be solved urgently in the province, promoting the economic society of Jilin province. Through the establishment of specialized think tank research and management institutions, the establishment of a materialized management system, the construction of the information base required by the think tank, to provide good office conditions, job security and service support systems for experts in the research of the think tank.

\section{Establish flexible Operation Mechanism of Talent}

Establish flexible operation mechanism of talent about supporting the university's intellectual resources, obtain the synergy innovation path and production, use the talent training mechanism task and project requirements. To establish a policy environment and management mode to attract and collect first-class talents from home and abroad; Innovate system mechanism, integrate quality resources, build a university think base brand; Research on the reform of project, and communities in project management, improve the quality of applied research project.

\section{Build a Feature Database, Database, and Think Tank Web site}

Construction of the higher education integration synergy innovation education centre of a think-tank, special database, database and think-tank, to form and share data with government, scientific research institutions, industry enterprises and other relevant departments, strengthen the research and consultation ability based on data analysis. To focus on the theoretical and practical problems of the scientific and economic development of Jilin province, To build a comprehensive research facility that promotes economic and social development in Jilin province.

\section{Establish a Channel for Good Communication}

To help school experts and researchers to cultivate problem sensitivity by regularly held influential high-end BBS, establish channels for good communication with superior authorities, education departments of jilin province, policy makers, media and social elites. A college think tank with "special, specialized, new, features", "Specialized" is characteristic of Jilin, "Specialized" is the 
characteristic of specialized applications, "New" is the idea, activity and organization form of scientific and technological innovation, "features" is the result of high-quality think tank.

\section{Regularly Published Results}

Through BBS, paper, publications of photoelectric teaching and research, reports of authoritative research, etc and to strengthen the publicity. Establish a rapid notification and release mechanism and enhance the "say" in the field of light, machine, power, etc.

\section{To Establish a Variety of Scientific and Technological Innovation Cooperation Mechanism Model}

This school is an engineering school with advantages of disciplines, the "schools and schools, schools and enterprises, schools and institutes" cooperation is the path, to carry out the research on the major strategic demand for the development of science and technology economy of countries and jilin province in new period, provide intellectual support for strong provinces and countries.

We have cooperated with more than ten universities in France, Britain and South Korea through the implementation of depth cooperation of school and enterprise, inter-school union; We have cooperated with 96 well-known domestic companies, such as Shenzhen huawei and jiantong; To work with jilin university, Changchun University of Science and Technology, Changchun University and Changchun Institute of Optics, Fine Mechanics and Physics Chinese Academy of Sciences, and so on and so on.

We strengthen the cooperation between schools and enterprises and actively promoted cooperative relations between the eight branches and related enterprises, Educational mode mainly have joint office, co-training engineer, joint research, joint production of products, forming a close cooperative relationship between school and enterprises, to promote combining learning, production and research.

\section{To Strengthen Evaluation Mechanism of the Teachers}

We strive to build a "double type" teachers, $60 \%$ of full-time teachers will standard in the three years; and create a part-time teaching team of engineers, corporate executives, and so on, share in the school of construction professional and discipline.

Our university has established a specialty about provincial Optical Information Sciences and Technology and Machine Design \&Manufacturing and Their Automation. Creates a provincial photovoltaic engineering, science, mechanical engineering, communication engineering experiment teaching center. Advanced manufacturing equipment manufacturing of two provincial engineering centers. Have built 6 provincial quality courses, 21 excellent courses, 2 professional teaching teams. Published 381 provincial articles in academic journals, get 16 education science award and 2 teaching achievement awards; publishing 22 materials and 51 Patent item. have established stable technological cooperation and university-enterprise cooperation in Jilin provincial 26 enterprises.108 teaching projects for nearly three years. The science research to 7.8 million yuan.

\section{Accelerate the Internationalization of Thinktank}

Use the school's international connections, draw on resources and experience from foreign universities, to build a better college think tank. Build international research and exchange networks, accelerate the international development of the thinktank, We have cooperated with more than ten universities in France, Britain and South Korea at present.

\section{Strengthen Interdisciplinary Research, Promote the Development of Relying on and Emerging Discipline}

Many problems in economic construction in jilin province require multidisciplinary consideration, and high school has a multi-disciplinary property. Universities have an irreplaceable advantage to prospective problems for university-enterprise cooperation, scientific and technological innovation. We need to build a school of light, machine, electricity and so on for the advantages of the economy 
of jilin province, constantly discovering new growth areas, promote the development of emerging disciplines.

\section{Acknowledgement}

This research was financially supported by the construction of a new think tank in Jilin province.

\section{References}

[1] Xi-Ting ZHANG, Education principle, Beijing Normal University press, 2003.

[2] Jun HE, Yang-Hua HUANG, Yun-Chang SHEN, University-enterprise cooperation in research of the optimal institutional arrangements, Chinese industrial economy,2011, (2): 151-160.

[3] Xue-Wen ZHANG, Open production, collaborative innovation, Studies in Science of Science, 2013, (4): 617-622.

[4] Zhen-Zhou TU, Xin GU, Based on the knowledge flow of collaborative innovation process of production, study and research, Studies in Science of Science, 2013, (9): 1381-1389.

[5] Jian-Qiu LI, Zhong-Quan QING, Co-innovation and higher vocational education, Researches in Higher Education of Engineering, 2013,(5): 118-122. 